\title{
Seed quality, chlorophyll content index and leaf nitrogen levels in maize inoculated with Azospirillum brasilense $e^{1}$
}

\author{
Qualidade de semente, índice de conteúdo de clorofila e teor nitrogênio foliar em \\ milho inoculado com Azospirillum brasilense
}

\author{
Lívia de Matos Pereira ${ }^{2}$, Elise de Matos Pereira ${ }^{2}$, Lucas Tadeu Mazza Revolti ${ }^{2}$, Sonia Marli Zingaretti ${ }^{3}$ e Gustavo \\ Vitti Môro'*
}

\begin{abstract}
The aim of this study was to evaluate differences between maize genotypes in relation to the germination response of the seeds and the growth of seedlings inoculated with Azospirillum brasilense, as well as the effect of inoculation on nitrogen levels and the chlorophyll content index of the leaves. The physiological seeds quality from the single-cross hybrids AG7098 and 2B707, and from the experimental synthetic varieties V2 and V4, inoculated with A. brasilense, was tested for germination, percentage and rate of emergence, and dry matter weight of the shoots and roots. Nitrogen levels and chlorophyll content index were evaluated in leaves of the same four genotypes grown in a greenhouse under different nitrogen supply systems and methods of inoculation with A. brasilense. The genotypes differ with regard to inoculation with A. brasilense. The hybrids were responsive to inoculation with A. brasilense for root dry matter weight. The V2 variety had a lower performance as regards root dry matter weight, with the opposite being seen for the dry matter weight of the shoots. V4 displayed no significant differences when inoculated. The results of the chlorophyll content index were not significant. Each genotype under evaluation displayed a different response for leaf nitrogen levels. It is possible to infer that the hybrids responded better to inoculation with the bacteria, with the greater root development leading to a better utilisation of water and nutrients.
\end{abstract}

Key words: Zea mays. Diazotrophic bacteria. Biological nitrogen fixation. Plant-bacteria interaction.

RESUMO - O objetivo deste estudo foi avaliar diferenças entre genótipos de milho quanto à resposta germinativa das sementes e crescimento de plântulas inoculadas com Azospirillum brasilense, assim como o efeito da inoculação no teor de nitrogênio e índice de conteúdo de clorofila foliar. A qualidade fisiológica de sementes dos híbridos simples, AG7098 e 2B707, e das variedades sintéticas experimentais, V2 e V4, inoculados com A. brasilense foi avaliada por meio de testes de germinação, porcentagem e velocidade de emergência e, massa de matéria seca de parte aérea e raiz. O teor de nitrogênio e o índice de conteúdo de clorofila foram avaliados em folhas dos mesmos quatro genótipos cultivados em casa de vegetação sob diferentes sistemas de fornecimento de nitrogênio e formas de inoculação com A. brasilense. Os genótipos diferem em relação à inoculação com A. brasilense. Os híbridos foram responsivos à inoculação com $A$. brasilense para massa de matéria seca de raiz. A variedade V2 apresentou comportamento inferior quanto à massa de matéria seca de raiz, mas o contrário foi observado para massa de matéria seca de parte aérea, e V4 não apresentou diferenças significativas quando inoculada. Os resultados de índice de conteúdo de clorofila não foram significativos. Para teor de nitrogênio foliar, cada genótipo avaliado respondeu de maneira particular. É possível inferir que os híbridos avaliados responderam melhor à inoculação com a bactéria, sendo que o maior desenvolvimento de raízes leva ao maior aproveitamento de água e nutrientes.

Palavras-chave: Zea mays. Bactérias diazotróficas. Fixação biológica de nitrogênio. Interação planta x bactéria.

\footnotetext{
DOI: $10.5935 / 1806-6690.20150047$

*Autor para correspondência

Recebido para publicação em 12/05/2014; aprovado em 14/04/2015

Parte da Tese de Doutorado da primeira autora apresentada ao Programa de Pós-Graduação em Genética e Melhoramento de Plantas da Universidade Estadual Paulista "Júlio de Mesquita Filho", Faculdade de Ciências Agrárias e Veterinárias, Campus de Jaboticabal. Bolsa de estudos financiada pela Capes/Coordenação de Aperfeiçoamento de Pessoal de Nível Superior

${ }^{2}$ Programa de Pós-Graduação em Genética e Melhoramento de Plantas da Universidade Estadual Paulista "Júlio de Mesquita Filho", Faculdade de Ciências Agrárias e Veterinárias, Campus de Jaboticabal, Jaboticabal-SP, Brasil, liviadematos@yahoo.com.br, elisedematospereira@yahoo. com.br, lucasrevolti@yahoo.com.br

${ }^{3}$ Universidade de Ribeirão Preto - Biotecnologia, soniazingaretti@hotmail.com

${ }^{4}$ Departamento de Produção Vegetal, Fitotecnia, Melhoramento Genético de Milho, Universidade Estadual Paulista "Júlio de Mesquita Filho", Faculdade de Ciências Agrárias e Veterinárias, Campusde Jaboticabal, Jaboticabal-SP, Brasil, gvmoro@ fcav.unesp.br
} 


\section{INTRODUCTION}

In maize (Zea mays L.), the increases in productivity from genetic improvement are evident; but the low average national productivity is directly linked to factors such as soil fertility and the low level of technology adopted when adding to the soil.

Standing out in this context is nitrogen fertilisation, which supplies the macronutrient most required and absorbed by the maize plants, and the most limiting to production. This element plays a part in the composition of vital molecules such as amino acids, proteins, enzymes and chlorophyll, which are related to leaf expansion, the increase in the photosynthetic rate, increased growth, development and plant production (OKUMURA et al., 2011).

The supply of nitrogen in the form of chemical fertiliser is one of the main factors affecting production costs in most crops. Despite being abundant in the atmosphere, nitrogen is the scarcest nutrient in virtually all types of soil in the forms metabolised by plants: nitrate and ammonium (OKUMURA et al., 2011).

Among the sustainable and efficient methods of nitrogen use is biological nitrogen fixation (BNF). The use of microorganisms which are beneficial to plants is recognised in species of the Fabaceae family, in the model of symbiosis which involves bacteria of the genus Rhizobium.

In addition, a large number of diazotrophic bacteria of the genus Azospirillum have been identified associated with the roots of plants of the Poaceae family, which are able to promote plant growth and BNF (BASHAN; HOLGUIN; DE-BASHAN, 2004), calling the attention of the scientific community to the potential benefits of this type of association.

Several contributions have been reported by researchers as a result of the interaction of plants with bacteria of the genus Azospirillum, among them are increases in the levels of chlorophyll, nitrogen, proline in the shoots and roots and of stomatal conductance, greater plant height, biomass production, grain yield, root development and tolerance to water stress, among others (LANA et al., 2012; SWEDRZYNSKA; SAWICKA, 2000; YADAV; YADAV; SINGH, 2011).

However, the results of this type of interaction are strongly affected by factors related to the soil, environment, plant genotype and/or bacteria (BRACCINI et al., 2012; DALLA SANTA et al., 2004). The way inoculation is carried out, via the seed or the soil, can alter the response of plants to interaction with the bacteria. The effect on the physiological seeds quality is therefore relevant, once much of the success in agriculture is based on the high quality of the seeds used; the seed being the vehicle of all the technology generated through breeding.

There is a growing search for better understanding of the interaction of Azospirillum spp. with the plant, in order to achieve efficiency in the use of diazotrophic bacteria in association with maize, aiming to make increases in productivity, besides reducing production costs and more sustainable agricultural practices with less pollutants (LANA et al., 2012).

Therefore, this work was carried out with the aim of verifying the effect of inoculation with Azospirillum brasilense on seed germination response and vigour, the chlorophyll content index and nitrogen in the leaves of maize.

\section{MATERIAL AND METHODS}

The trials were conducted under controlled conditions in the laboratory and greenhouse of the Department of Plant Production, at the Faculdade de Ciências Agrárias e Veterinárias of the Universidade Estadual Paulista "Júlio de Mesquita Filho" (FCAV-UNESP), in the state of São Paulo, Brazil.

Four maize genotypes were evaluated, two commercial single-cross hybrids (AG7098 and 2B707) and two experimental synthetic varieties, known as V2 and V4, that are in the process of being registered with Ministry of Agriculture Livestock and Supply (MAPA). The seeds used had earlier been provided and treated with fungicide and insecticide by the seed production companies.

Inoculation with Azospirillum brasilense was carried out using a commercial product containing the AbV5 AbV6 strains in a liquid formulation at the minimum concentration of $5 \cdot 10^{8}$ cells $\mathrm{mL}^{-1}$ (Qualyfix Gramínea, Brasilquímica) at dosages suggested by the manufacturer, corresponding to $4 \mathrm{~mL} \mathrm{kg-1} \mathrm{for} \mathrm{inoculation} \mathrm{via} \mathrm{the} \mathrm{seeds,} \mathrm{as} \mathrm{used} \mathrm{in} \mathrm{both}$ experiments and $600 \mathrm{~mL} \mathrm{~h}^{-1}$ for inoculation via the soil.

Inoculation of the seeds was carried out when sowing. The seeds were placed into plastic bags, weighed, the indicated volume of inoculum was added and then homogenised. For inoculation via the soil, the volume of inoculant was distributed over the ground, parallel to the plants, with the aid of an automatic pipette 30 days after emergence.

The experiment for seed quality was conducted in a completely randomised design with four replications of 50 seeds.

The physiological seeds quality of the four genotypes inoculated with $A$. brasilense was evaluated by means of tests of germination and vigour. 
The germination test was prepared on rolls of paper towels (Germitest), which had been previously moistened with distilled water in the proportion of 2.5 times the initial weight; the seeds being arranged with the aid of a perforated plate. They were then placed into germinators, according to the criteria recommended in the Regras de Análise de Sementes (BRASIL, 2009). The count of the seedlings classified as normal was made seven days after sowing and the results expressed as a percentage.

For the test of seedling emergence, the seeds were distributed in plastic trays containing a 2:1 mixture of sand and earth. After sowing, the trays were kept in a plant growth room at $25{ }^{\circ} \mathrm{C}$ and a photoperiod of 12 hours. Irrigation was carried out every two days, with the necessary amount of water being calculated to maintain about $70 \%$ of field capacity for the substrate. Counts of emerged seedlings were made daily until the stand had stabilised, which took place 14 days after sowing, after which time the percentage of normal seedlings at 14 days was considered, and the emergence speed index (ESI) determined using the formula proposed by Maguire (1962).

In addition, the dry matter weight of the shoots (DMS) and roots (DMR) was evaluated using four replications of 25 seedlings collected at the end of the emergence test, which were dried in a forced ventilation oven $\left(65^{\circ} \mathrm{C}\right)$ for 72 hours, with the DM then being assessed. Calculations were made by dividing the dry matter weight by the number of seedlings (NAKAGAWA, 1999) and the results expressed in mg seedling $^{-1}$.

The second experiment was set up in a greenhouse, where the four genotypes were sown in pots with a capacity of $12 \mathrm{dm}^{3}$, which were filled with a typical eutrophic Red Latosol, of a clayey texture.

The trial was conducted in an experimental design of randomised blocks, in $4 \times 6$ factorial scheme (genotype $\mathrm{x}$ treatment), with three replications, each experimental plot comprising two pots of two plants each. The four genotypes received the following treatments: 1) control, with no inoculation and no topdressing of $\mathrm{N}$; 2) inoculation via the seeds with $A$. brasilense with no topdressing of $\mathrm{N} ; 3$ ) inoculation via the seeds and topdressing of $100 \mathrm{~kg} \mathrm{~N} \mathrm{ha}^{-1}$; 4) inoculation via the soil with no topdressing of $\mathrm{N} ; 5$ ) inoculation via the soil and topdressing of $100 \mathrm{~kg} \mathrm{Nha}^{-1}$; 6) No inoculation and topdressing of $100 \mathrm{~kg} \mathrm{~N} \mathrm{ha}^{-1}$. All the pots received an NPK formulation (8-28-16) as a base fertiliser according to recommendations for the crop, and for those treatments where a topdressing of $\mathrm{N}$ was applied 30 days after emergence (DAE), urea ( $45 \%$ soluble $\mathrm{N}$ ) was used as the source. The pots received daily, uniform irrigation.
The third fully-expanded leaf, counted from the apex, was collected 55 days after emergence (FERREIRA et al., 2002) from the two plants in each lot when these presented 10 or 11 fully-expanded leaves.

Readings of the chlorophyll index were taken when the leaves were collected: between 10:00 and 14:00, when the sun's position is favourable to the use of a chlorophyll meter. The reading was taken from the central region of the leaves at the side of the midrib, using the CCM-200 chlorophyll meter (Opti-Sciences, Inc.) to obtain data on the chlorophyll content index (CCI).

The leaves were rinsed three times with deionised water, then placed into paper bags and dried in a forced ventilation oven at $\pm 65^{\circ} \mathrm{C}$. The midrib was then removed from the leaves, which were ground using a mechanical Wiley mill. The total nitrogen was removed by hot sulphuric acid digestion, as described by Bataglia et al. (1983).

The data for germination percentage and emergence, DMS, DMR, CCI and NC underwent variance analysis and the F-test $(\mathrm{P}<0.05)$, with the means being compared by Tukey test $(\mathrm{P}<0.05)$. To check for normal distribution of the data, the Kolmogorov-Smirnov normality test was used. Only the data for germination percentage and emergence required transformation, this being done by square root $(\sqrt{ } \mathrm{x})$. All analyses were carried out using the Statistical Analysis System v.9 software (SAS, 2002).

\section{RESULTS AND DISCUSSION}

Inoculation of the seeds of the four maize genotypes with $A$. brasilense did not affect the germination percentage (Table 1). However, all showed a high percentage of germination, above the $85 \%$ minimum required for marketing, as established by the MAPA, IN no 45, of 17 September 2013. The germination percentage for the AG7098, 2B707, V2 and V4 genotypes were 95, 98, 91 and $94 \%$ respectively.

The genotypes responded differently to inoculation as regards the dry matter weight of the shoots (DMS) and roots (DMR) (Table 1).

The results for germination, emergence and ESI demonstrate the feasibility of using inoculants via the seeds in maize.

Similarly, for seeds of three wheat cultivars inoculated with the AbV5 and AbV6 strains of A. brasilense, no effect from the inoculation was noted on seed germination (RAMPIM et al., 2012).

Inoculation with $A$. brasilense affected negatively the percentage and speed of emergence, however this 
difference is very small, and in practical terms does not result in any differences between the treatments. A difference was detected probably because the CV (\%) is very low and minimal differences may therefore be statistically significant (Tables 1 and 2).

In maize seeds it was not possible to see any effect from inoculation with $A$. brasilense on the final germination percentage or ESI, according to a study by Barilli et al. (2011). Unlike in rice seeds, where it was observed that inoculation with strains of the genus Azospirillum gave a higher emergence speed and less contamination by fungi (ARAÚJO et al., 2010).

The AG7098 and 2B707 hybrids showed a significant increase in DMR, of 113.65 and $17.74 \%$ respectively, in the presence of $A$. brasilense, with no response for DMS (Table 3).

For the V2 variety, an increase of $28.35 \%$ in DMS was seen when inoculated with A. brasilense, moreover, inoculation had a negative effect on DMR. The V4 variety did not respond to inoculation (Table 3).

The increase in DMS may lead to a greater production of biomass and consequently to higher productivity. According to Lana et al. (2012), inoculation with $A$. brasilense promoted an increase in productivity and shoot dry weight in maize.

After inoculation with the AbV5 and AbV6 strains of $A$. brasilense, contributions to root growth and productivity in maize and wheat were noted in field trials (HUNGRIA et al., 2010).
Also, maize plants that received half of the nitrogen dosage and were inoculated with A. brasilense showed values for plant dry weight similar to those treatments which received $100 \%$ of the nitrogen dosage, and greater than those plants that were not inoculated with A. brasilense (BRACCINI et al., 2012). Similarly, inoculation with $A$. amazonense promoted an increase in root dry weight production in maize plants; however, there was no effect from the bacteria on shoot dry weight (REIS JUNIOR et al., 2008).

The influence of inoculating with A. brasilense on root development in hybrids is therefore evident. This is directly linked to the land-exploitation potential of the plants. Although not completely meeting plant requirements for $\mathrm{N}$, diazotrophic bacteria may greatly influence the nitrogen nutrition of crops, which is indirectly related to increases in the root system (MANTELIN; TOURAINE，2004; STEENHOUDT; VANDERLEYDEN, 2000).

It is therefore possible to infer that the hybrids under evaluation can respond more promisingly to inoculation with the bacteria, since greater root development may increase the capacity of the plants to absorb water and nutrients, thus making them more vigorous and productive, and as a consequence more tolerant to the adverse conditions of drought, salinity and pathogenicity (HUNGRIA et al., 2010;. MANTELIN; TOURAINE, 2004).

Inoculation with $A$. brasilense plus nitrogen fertilisation did not affect the chlorophyll content index

Table 1 - Summary of the variance analysis, with the mean squares and their respective significance for germination (G), emergence (E), emergence speed index (ESI), root dry matter weight (DMR) and shoot dry matter weight (DMS), in corn genotypes inoculated with Azospirillum brasilense

\begin{tabular}{lcccccc}
\hline SV & DF & G & E & ESI & DMR & DMS \\
\hline Genotype & 3 & $0.167^{\mathrm{ns}}$ & $0.011^{\mathrm{ns}}$ & $0.787^{\mathrm{ns}}$ & $1962.860^{* *}$ & $519.138^{* *}$ \\
Inoculation & 1 & $0.043^{\mathrm{ns}}$ & $0.160^{*}$ & $2.582^{*}$ & $985.347^{* *}$ & $36.125^{\mathrm{ns}}$ \\
Genotype x Inoculation & 3 & $0.119^{\mathrm{ns}}$ & $0.039^{\mathrm{ns}}$ & $0.517^{\mathrm{ns}}$ & $2789.499 * *$ & $96.832^{*}$ \\
Residual & 24 & 0.081 & 0.024 & 0.455 & 65.559 & 24.652 \\
CV $(\%)$ & & 2.93 & 1.59 & 5.76 & 8.26 & 9.55 \\
\hline
\end{tabular}

SV source of variation; DF degrees of freedom; ** and * significant by F-test at $1 \%$ and $5 \%$ probability respectively; ns not significant by F-test

Table 2 - Percentage of emergence and emergence speed index (ESI) in seeds of maize of genotypes inoculated with Azospirillum brasilense

\begin{tabular}{lcc}
\hline Inoculation Azospirillum & Emergence (\%) & ESI \\
\hline Without & $98 \mathrm{a}$ & $12,00 \mathrm{a}$ \\
With & $95 \mathrm{~b}$ & $11.43 \mathrm{~b}$ \\
\hline
\end{tabular}

Mean values followed by the same letter in a column do not differ by Tukey test at $5 \%$ probability 
Table 3 - Root dry matter weight (DMR) and shoot dry matter weight (DMS) in mg per seedling, grown from the seeds of maize genotypes inoculated with Azospirillum brasilense

\begin{tabular}{lcccc}
\hline \multirow{2}{*}{ Inoculation Azospirillum } & \multicolumn{5}{c}{ Genotype } \\
\cline { 2 - 5 } & AG7098 & 2B707 & V2 & V4 \\
\hline Without & $50.85 \mathrm{Bb}$ & $99.40 \mathrm{Ab}$ & $106.41 \mathrm{Aa}$ & $113.03 \mathrm{Aa}$ \\
With & $108.64 \mathrm{Aa}$ & $117.03 \mathrm{Aa}$ & $74.40 \mathrm{Bb}$ & $114.01 \mathrm{Aa}$ \\
\hline & & MAS & $38.10 \mathrm{Cb}$ & $49.40 \mathrm{Ba}$ \\
\hline Without & $63.60 \mathrm{Aa}$ & $52.70 \mathrm{Ba}$ & $46.90 \mathrm{BCa}$ & $46.10 \mathrm{Ca}$ \\
\hline
\end{tabular}

Mean values followed by the same uppercase letter in a row or lowercase letter in a column do not differ by Tukey test at $5 \%$ probability

(CCI) in the genotypes being evaluated. There were however differences in CCI between genotypes (Table 4).

For leaf nitrogen content (NC), a significant interaction was seen between the methods for supplying nitrogen and genotype, suggesting that the responses of the evaluated genotypes were different in respect to the treatment received (Table 4).

Generally, an increase in chlorophyll content is considered to be a parameter which corresponds to an increase in photosynthesis, and consequently to an increase in production potential and plant vigour (BASHAN et al., 2006; SWEDRZYNSKA; SAWICKA, 2000).

Inoculation with A.brasilense in wheat promoted an increase in photoprotective and auxiliary photoprotective pigments that benefit plant growth. In this study, the authors suggest that the Azospirillumplant interaction may involve multiple mechanisms of action which are triggered simultaneously, such as hormonal action, nitrogen fixation and mineral absorption (BASHAN et al., 2006).
The AG7098 hybrid presented a greater CCI than the other genotypes. This can be considered a characteristic of the genotype (Table 5).

Assessing the leaf chlorophyll content in maize inoculated with $A$. brasilense under different dosages of nitrogen, it was found that an increase in chlorophyll content was proportional to the dosages of $\mathrm{N}$, with there being a positive effect from inoculation (JORDÃO et al., 2010).

Although for some maize genotypes no correlation was seen between CCI and leaf NC (ROCHA et al., 2005), leaf chlorophyll content can be a viable alternative for indicating the level of $\mathrm{N}$ in the plant (SILVA et al., 2008).

As for the leaf $\mathrm{NC}$, when analysing each genotype individually, it can be seen that for AG7098, inoculation via the seeds with $A$. brasilense together with the nitrogen topdressing (treatment 3) or conventional nitrogen fertiliser (treatment 6) provided similar values, greater than inoculation via the seeds with no topdressing of $\mathrm{N}$ (treatment 2), which resulted in a lower value for $\mathrm{NC}$ (Table 6).

Table 4 - Summary of the variance analysis, with mean squares, for the chlorophyll content index (CCI) and nitrogen content (NC) in leaves under different methods of inoculation with Azospirillum brasilense and supplies of nitrogen fertiliser

\begin{tabular}{lccc}
\hline \multicolumn{1}{c}{ Source of Variation } & DF & CCI & NC \\
\hline Block & 2 & $33.5617^{* * *}$ & $38.840^{* *}$ \\
Treatment & 5 & $12.283^{\text {ns }}$ & $24.841^{* *}$ \\
Genotype & 3 & $90.954^{* *}$ & $1.839^{\text {ns }}$ \\
Treatment x Genotype & 15 & $15.558^{\text {ns }}$ & $36.826^{* *}$ \\
Residual & 118 & 18.680 & 3.572 \\
CV $(\%)$ & & 13.31 & 5.33 \\
\hline
\end{tabular}

DF degrees of freedom; ** significant by F-test at 5\% probability; ns not significant by F-test at 5\% probability 
Table 5 - Chlorophyll Content Index (CCI) in leaves of maize genotypes under different methods of inoculation with Azospirillum brasilense and supplies of nitrogen fertiliser

\begin{tabular}{lll}
\hline & Genotype & CCI \\
\hline AG7098 & $34.82 \mathrm{a}$ \\
2B707 & $31.38 \mathrm{~b}$ \\
V2 & $32.03 \mathrm{~b}$ \\
V4 & $31.64 \mathrm{~b}$ \\
\hline
\end{tabular}

Mean values followed by the same letter do not differ by Tukey test at $5 \%$ probability

Table 6 - Leaf nitrogen content $\left(\mathrm{g} \mathrm{kg}^{-1}\right)$ in maize genotypes under different methods of inoculation with Azospirillum brasilense and supplies of nitrogen fertiliser

\begin{tabular}{|c|c|c|c|c|}
\hline \multirow{2}{*}{ Treatment } & \multicolumn{4}{|c|}{ Genotype } \\
\hline & AG7098 & 2B707 & $\mathrm{V} 2$ & V4 \\
\hline \multicolumn{5}{|c|}{$\mathrm{NC}$} \\
\hline 1 & $35.76 \mathrm{Aab}$ & $31.01 \mathrm{Cc}$ & $34.63 \mathrm{ABab}$ & $32.63 \mathrm{BCc}$ \\
\hline 2 & $33.76 \mathrm{Bb}$ & $38.26 \mathrm{Aa}$ & $36.01 \mathrm{ABab}$ & $33.88 \mathrm{Bc}$ \\
\hline 3 & $37.75 \mathrm{Aa}$ & $34.13 \mathrm{Bbc}$ & $35.51 \mathrm{ABab}$ & $34.76 \mathrm{Bbc}$ \\
\hline 4 & $34.88 \mathrm{Bab}$ & $33.76 \mathrm{Bbc}$ & 34.76 Bab & $41.13 \mathrm{Aa}$ \\
\hline 5 & 35.13 BCab & $38.26 \mathrm{Aa}$ & 37.76 Aba & $34.01 \mathrm{Cc}$ \\
\hline 6 & $36.51 \mathrm{Aa}$ & $35.76 \mathrm{ABab}$ & $33.51 \mathrm{Bb}$ & $37.88 \mathrm{Ab}$ \\
\hline
\end{tabular}

Mean values followed by the same letter, uppercase in a row and lowercase in a column, do not differ by Tukey test at 5\% probability. 1) Control, with no inoculation and no topdressing of N. 2) Inoculation via the seeds with A. brasilense with no topdressing of N. 3) Inoculation via the seeds and topdressing of $100 \mathrm{~kg} \mathrm{~N} \mathrm{ha}^{-1}$.4) Inoculation via the soil with no topdressing of N. 5) Inoculation via the soil and topdressing of $100 \mathrm{~kg} \mathrm{~N}$ ha-1. 6) No inoculation and topdressing of $100 \mathrm{~kg} \mathrm{~N} \mathrm{ha}^{-1}$

The 2B707 hybrid proved to be responsive both to inoculation via the seeds with $A$. brasilense and no $\mathrm{N}$ topdressing (treatment 2), and to inoculation via the soil and the topdressing of nitrogen fertiliser (treatment 5). In turn, the control (treatment 1), was inferior to the other treatments (Table 6). According to the results, this hybrid could dispense with nitrogen fertiliser as topdressing when inoculated via the seeds with $A$. brasilense for the same leaf NC.

The V2 variety displayed a higher NC when inoculated with $A$. brasilense via the soil in relation to the treatment that received only a topdressing of $\mathrm{N}$ in the fertiliser (treatment 6) (Table 6). Inoculation with A. brasilense via the soil therefore contributed to the better response of the V2 variety, even when the full nitrogen dosage as recommended for maize was given.

The V4 variety presented greater leaf $\mathrm{NC}$ when inoculation with $A$. brasilense was via the soil (treatment 4), followed by the topdressing of $\mathrm{N}$ (treatment 6) (Table 6). In view of this, the V4 variety could dispense with the topdressing of fertiliser, if inoculation were via the soil, resulting in the same leaf NC.
Similar results were reported in relation to the different behaviour of wheat genotypes inoculated with A. brasilense, with an increase in shoot nitrogen content of 35.3 and $22.4 \%$ being seen in two of the five wheat cultivars being evaluated (CD 108 and CD 150 respectively) (LEMOS et al., 2013). An increase in nitrogen content was also seen in wheat plants whose seeds had been inoculated with $A$. brasilense and with no nitrogen being supplied (RODRIGUES et al., 2000).

Inoculation with $A$. brasilense provided higher nitrogen uptake at the post-anthesis stage in wheat, which although not increasing production, promoted the accumulation of nitrogen and dry matter weight of the straw. In this study, the topdressing of nitrogen fertiliser $\left(45 \mathrm{~kg} \mathrm{ha}^{-1} \mathrm{~N}\right)$ was able to be replaced when inoculation was via the seeds plus $15 \mathrm{~kg} \mathrm{ha}^{-1}$ of $\mathrm{N}$ when planting (DIDONET; RODRIGUES; KENNER, 1996).

The nitrogen content of the roots of maize plants under different regimes and sources of nitrogen was increased when these were inoculated with $A$. amazonense (REIS JUNIOR et al., 2008). 
On the other hand, there was no contribution from the inoculation of a mixture of diazotrophic bacteria $(A$. lipoferum, A. amazonense and Burkholderiakururiensis) in nine maize genotypes evaluated as to accumulated nitrogen content (MENDONCA; URQUIAGA; REIS, 2006).

Out of 12 maize genotypes inoculated with a mixture of strains of Azospirillum spp., two (Morgan 318 and Dekalb 4D-70) displayed an increase in grain production equivalent to the application of $100 \mathrm{~kg} \mathrm{~N} \mathrm{ha}^{-1}$. In this study, growing plants in soil containing labelled-N15, has shown that responses of nitrogen accumulation were due to biological nitrogen fixation. Therefore, if the appropriate genotypes are selected, nitrogen fertilisation can be partially replaced by inoculation with Azospirillum spp. (GARCIA DE SALAMONE et al., 1996).

The success achieved by inoculation with Azospirillum spp. in grasses is influenced by such factors as the strain used, the physiological stage of the plant at the time of inoculation, the affinity of the strain to the bacteria and the plant genotype (BALDANI; BALDANI, 2005; BRACCINI et al., 2012).

Further studies with $A$. brasilense and maize genotypes are needed for the use of these bacteria to become feasible and to enjoy the benefits that this type of microorganism can bring to crops, since they show promise in promoting effects in those characteristics related to increases in productivity, when the appropriate interactions are used.

\section{CONCLUSIONS}

1. The physiological seeds quality does not change with inoculation with $A$. brasilense;

2. The genotypes respond differently to inoculation with $A$. brasilense, with the hybrids responding better to the bacteria as regards root dry matter weight;

3. Inoculation of maize genotypes with $A$. brasilense and nitrogen fertilisation do not influence the chlorophyll content index, they do however change the leaf nitrogen content differently for each genotype.

\section{REFERENCES}

ARAÚJO, A. E. S. et al. Germinação e vigor de sementes de arroz inoculadas com bactérias diazotróficas. Ciência e Agrotecnologia, v. 34, n. 4, p. 932-939, 2010.

BALDANI, J. I.; BALDANI, V. L. D. History on the biological nitrogen fixation research in graminaceous plants: special emphasis on the Brazilian experience. Anais da Academia Brasileira de Ciências, v. 77, n. 3, p. 549-579, 2005.
BARILLI, D. R. et al. Eficiência na inoculação do milho com Azospirillum brasilense em diferentes períodos antes da semeadura. In: CONGRESSO BRASILEIRO DE AGROECOLOGIA, 7., 2011, Fortaleza. Resumos... Fortaleza: Cadernos de Agroecologia, v. 6, n. 2, p. 1-5, 2011.

BASHAN, Y. et al. Increase in auxiliary photoprotective photosynthetic pigments in wheat seedlings induced by Azospirillum brasilense. Biology and Fertility of Soils, v. 42, n. 1, p. 279-285, 2006.

BATAGLiA, O. C. et al. Métodos de análise química de plantas. Boletim técnico do Instituto Agronômico de Campinas, v. 78, p. 48, 1983.

BASHAN, Y.; HOLGUIN, G.; DE-BASHAN, L. E. Azospirillumplant relations physiological, molecular, agricultural, and environmental advances (1997-2003). Canadian Journal of Microbiology, v. 50, n. 8, p. 521-577, 2004.

BRACCINI, A. L. et al. Seed Inoculation with Azospirillum brasilense, Associated with the Use of Bioregulators in Maize. Revista Caatinga, v. 25, n. 2, p. 58-64, 2012.

BRASIL. Ministério daAgricultura, Pecuária e Abastecimento. Regras para análise de sementes. Brasília, DF: SDA/ACS, 2009. 399 p.

DALLA SANTA, O. R. et al. Effects of inoculation of Azospirillum sp. in maize seeds under field conditions. Journal of Food, Agriculture \& Environment, v. 2, n. 1, p. 238-242, 2004.

DIDONET, A. D.; RODRIGUES, O.; KENNER, M. H. Acúmulo de nitrogênio e de massa seca em plantas de trigo inoculadas com Azospirillum brasilense. Pesquisa Agropecuária Brasileira, v. 31, n. 9, p. 645-651, 1996.

FERREIRA, V. M. et al. Metabolismo do nitrogênio associado à deficiência hídrica e sua recuperação em genótipos de milho, Ciência Rural, v. 32, n. 1, p. 13-17, 2002.

GARCIA DE SALAMONE, I. E. et al. Biological nitrogen fixation in Azospirillum strain-maize genotype associations as evaluated by the $15 \mathrm{~N}$ isotope dilution technique. Biology and Fertility of Soils, v. 23, n. 1, p. 249-256, 1996.

HUNGRIA, M. et al. Inoculation with selected strains of Azospirillum brasilense and A. lipoferum improves yields of maize and wheat in Brazil. Plant and Soil, v. 331, n. 1-2, p. 413-425, 2010.

JORDÃO, L. T. et al. Teor relativo de clorofila em folhas de milho inoculado com Azospirillum brasiliense sob diferentes doses de nitrogênio e manejo com braquiária. In: REUNIÃO BRASILEIRA DE FERTILIDADE DO SOLO E NUTRIÇÃO DE PLANTAS, 29. REUNIÃO BRASILEIRA SOBRE MICORRIZAS, 13. SIMPÓSIO BRASILEIRO DE MICROBIOLOGIA DO SOLO, 11. REUNIÃO BRASILEIRA DE BIOLOGIA DO SOLO, 8., 2010, Guarapari. Anais... Guarapari: FERTBIO, 2010. 1 CD-ROM.

LANA, M. C. et al. Inoculation with Azospirillum, associated with nitrogen fertilization in maize. Revista Ceres, v. 59, n. 3, p. $399-405,2012$. 
LEMOS, J. M. et al. Resposta de cultivares de trigo à inoculação de sementes com Azospirillum brasilense, e à adubação nitrogenada em cobertura. Científica, v. 41, n. 2, p. 189-198, 2013.

MAGUIRE, J. D. Speed of germination aid in selection and evaluation for seedling and vigour. Crop Science, v. 2, n. 2, p. 176-177, 1962.

MANTELIN, S.; TOURAINE, B. Plant growth-promoting bacteria and nitrate availability: impacts on root development and nitrate uptake. Journal of Experimental Botany, v. 55, n. 394, p. 27-34, 2004.

MENDONÇA, M. M; URQUIAGA, S. S.; REIS, V. M. Variabilidade genotípica de milho para acumulação de nitrogênio e contribuição da fixação biológica de nitrogênio. Pesquisa Agropecuária Brasileira, v. 41, n. 11, p. 1681-1685, 2006.

NAKAGAWA, J. Testes de vigor baseados no desempenho das plântulas. In: KRZYZANOWSKI, F. C.; VIEIRA, R. D.; FRANÇA NETO, J. B. Vigor de sementes: conceitos e testes. 1. ed. Londrina: ABRATES, 1999. cap. 2, p. 2-24.

OKUMURA, R. S. et al. Influence of different nitrogen levels on growth and production parameters in maize plants. Journal of Food, Agriculture \& Environment, v. 9, n. 3, p. 510-514, 2011.

RAMPIM, L. et al. Qualidade fisiológica de sementes de três cultivares de trigo submetidas à inoculação e diferentes tratamentos. Revista Brasileira de Sementes, v. 34, n. 4, p. 678$685,2012$.

REIS JUNIOR, F. B. et al. Inoculação de Azospirillum amazonense em dois genótipos de milho sob diferentes regimes de nitrogênio. Revista Brasileira Ciência Solo, v. 32, n. 1, p. 1139-1146, 2008.
ROCHA, R. N. C. O. et al. Relação do índice SPAD, determinado pelo clorofilômetro, com teor de nitrogênio na folha e rendimento de grãos em três genótipos de milho. Revista Brasileira de Milho e Sorgo, v. 4, n. 2, p. 161-171, 2005.

RODRIGUES, O. et al. Nitrogen translocation in wheat inoculated with Azospirillum and fertilized with nitrogen. Pesquisa Agropecuária Brasileira, v. 35, n. 7, p. 14731481, 2000.

SAS INSTITUTE INC. Statistical Analysis System User's Guide. Version 9.0. 2.ed.(?) Cary: SAS Institute, 2002. 513 p.

SILVA, L.S. et al. Leitura crítica do clorofilômetro para manejo da adubação nitrogenada na cultura do arroz irrigado por alagamento. Revista Brasileira de Agrociência, v. 14, n. 4, p. 125-127, 2008.

STEENHOUDT, O.; VANDERLEYDEN, J. Azospirillum, a free-living nitrogen-fixing bacterium closely associated with grasses: genetic, biochemical and ecological aspects. FEMS Microbiology Reviews, v. 24, n. 4, p.487-506, 2000.

SWĘDRZYNSKA, D.; SAWICKA, A. Effect of Inoculation with Azospirillum brasilense on Development and Yielding of Maize (Zea mays ssp. Saccharata L.) under Different Cultivation Conditions. Polish Journal of Environmental Studies, v. 9, n. 6, p. 505-509, 2000.

YADAV, S.; YADAV, J.; SINGH, S.G. Performance of Azospirillum for improving growth, yield and yield attributing characters of maize (Zea mays L.) in presence of nitrogen fertilizer. Research Journal of Agricultural Sciences, v. 2, n. 1, p. 139-141, 2011. 